Gazi University
Journal of Science
$\mathrm{http} / /$ dergipark.gov.tr/gujs

\title{
Investigation of Thermomechanical Processing of Nb Microalloyed Steel Produced by Powder Metallurgy
}

\author{
Demet TASTEMUR ${ }^{1}$ (D) , Suleyman GUNDUZ ${ }^{1, *}$ (D) Mehmet Akif ERDEN $^{2}$ \\ ${ }^{1}$ Karabük University - Faculty of Technology, Manufacturing Engineering, 78050, Karabük, Turkey \\ ${ }^{2}$ Karabük University - Faculty of Engineering, Biomedical Engineering, 78050, Karabük, Turkey \\ Highlights \\ - The study focused on the thermomechanical processing behavior for $\mathrm{Nb}$ microalloyed steel. \\ - P/M was used as the production method. \\ - Mechanical properties and microstructures were characterized for different conditions.
}

\begin{tabular}{l} 
Article Info \\
\hline \\
Received: 03 Dec 2020 \\
Accepted: 06 July 2021 \\
Keywords \\
Microalloyed steel \\
Powder metallurgy \\
Thermomechanical \\
Processing \\
Mechanical properties
\end{tabular}

\section{INTRODUCTION}

Microalloyed steels with high strength and toughness can easily be welded due to their low carbon content. Both strength and toughness of microalloyed steels are increased by using the effect of thermomechanical processing and microalloying elements [1,2]. These steels are used to produce the forged parts with fine grain sizes using a thermomechanical process. The effect of microalloying on steel depends on the conditions of the applied plastic deformation. Microalloying elements that are free in the solution increase the recrystallization temperature of austenite, thereby causing a decrease in the recovery rate of the grains $[3,4]$. In addition, the formed precipitates reduce the recrystallization rate and prevent growth of the austenite during or after the deformation [5,6]. The microalloyed steels have been produced to achieve optimum mechanical properties which are obtained by controlling the parameters of thermomechanical process such as temperature and strain rate [7]. Mechanical properties of microalloyed steel can also be enhanced by taking advantage of the precipitation hardening and grain refining effects of microalloy elements such as titanium, niobium and vanadium.

An important property of microalloyed steels is the different microstructures which are achieved by changing the composition and thermomechanical process parameters. During hot deformation of low carbon unalloyed steels, the change of microstructure is not evident as observed in microalloyed steels containing niobium, vanadium, titanium, molybdenum, aluminum or boron elements in single or 
combination. The microalloying addition to low carbon steels influence the kinetics of phase transformation and increase the precipitation hardening in ferrite phase. Niobium has the strongest effect on these properties among the microalloying elements. In the hot deformation of microalloyed steels, the inhomogeneity of the initial austenite microstructure has an important effect on the structure of the finished product. The effect of hot deformation on the microstructure, the precipitation process and the effect of the resulting defects (subgrains, dislocations and deformation bands) are difficult and expensive to detect under industrial conditions $[8,9]$. The addition of niobium to steel causes the niobium carbide and niobium nitride to precipitate within the structure of the steel. These ingredients refine the grain size, delay recrystallization and ensure precipitation hardening. The grain refining effect of $\mathrm{Nb}$ is mainly related to the retard in recrystallization. In addition, $\mathrm{Nb}$ decreases the austenite ferrite transformation temperature, simultaneously increasing the ferrite nucleation rate and decreasing the grain growth rate. This effect leads to a fine-grained transformation structure that also increases strength, toughness and ductility. A range of structural steels (line pipe, automotive, construction) with a yield strength greater than and above $\sim 350 \mathrm{MPa}$ contain niobium to achieve the right balance of strength, toughness and weldability [10]. Gündüz et al. showed in their study that the strength of microalloyed PM steel increased by precipitation hardening and grain refining with the addition of $\mathrm{Nb}$. They pointed out in their study that $\mathrm{NbC}(\mathrm{N})$ precipitates prevent grain growth during the sintering step and this causes an increase in strength [11]. Özdemirler et al. [12] also showed that when the $\mathrm{NbC}$ amount increased to $0.2 \%$ by weight, the yield strength, tensile strength and hardness values of P/M steel increased. They attributed the increase in mechanical properties to precipitation hardening and decrease in precipitate particle size. As a matter of fact, fine grained structure and precipitate particle improve the mechanical properties by preventing the dislocation movement.

The difficulty and cost of the production stages of microalloyed steels lead to the development of new systems for the production of these steels with powder metallurgy. Despite its low alloy content, microalloying leads to great increase in strength and toughness which is resulted of the formation of carbonitrides. The contribution of these effects depends on different thermal and mechanical treatment in powder metallurgy (P/M) compared to conventional steel production using forging and casting methods. The traditional powder metallurgy method includes powder production, cold pressing and sintering [13]. The structure of the materials produced by this method is porous and the density is low compared to the materials produced by the conventional casting method. This may cause a decrease in mechanical properties. Porous structure restricts the use of materials in high strength applications by causing the stresses increment [14]. It is indicated in the literature that the application of hot deformation to the materials produced by the powder metallurgy causes to exhibit better mechanical properties than the materials produced by the casting and forging method [15].

Powder metallurgy (PM) is a metal forming technology that uses powders (metallic and or ceramic) as raw materials that are formed into a specific shape and size and then sintered at high temperature [16]. Although powder metallurgy $(\mathrm{P} / \mathrm{M})$ is not a new known process, it only started to be used as an industrial process in the early 20th century. It is widely used in developed countries of the world, and its products find wide application areas in the industry. By using the P/M method, some parts that are difficult to produce and process with other methods can be easily produced in the intended composition [17,18]. In Figure 1, the route followed by the conventional P/M method is given.

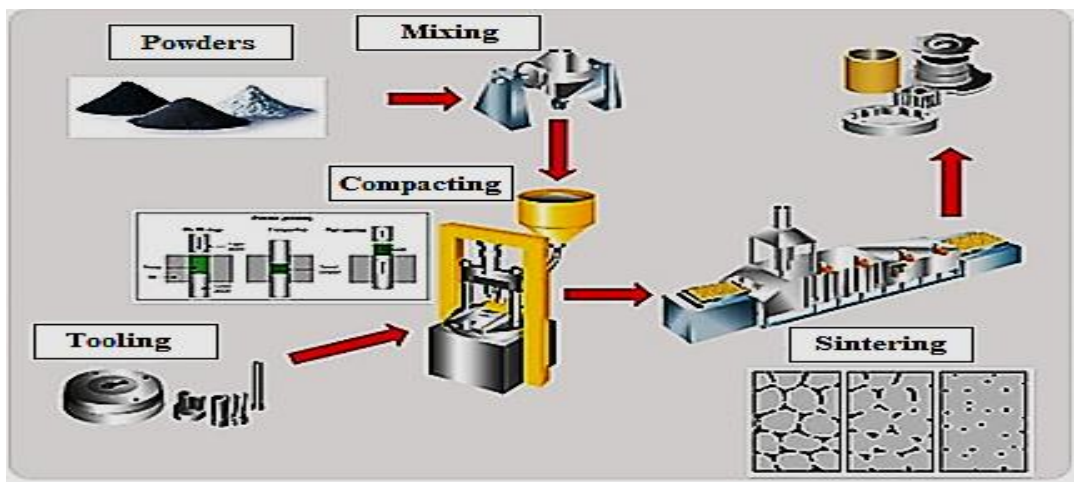

Figure 1. PM chart. Conventional powder metallurgy route [19] 
In this study, thermomechanical processing behavior of unalloyed and $\mathrm{Nb}$ microalloyed steel was investigated. The properties of these steels were also compared with each other. Mechanical properties and microstructures were analysed for different conditions to determine the grain refinement and precipitation strengthening.

\section{MATERIAL METHOD}

In the present study, two types of steels with compositions of $\mathrm{Fe}-0.35 \mathrm{C}$ (wt $\%$, unalloyed steel) and $\mathrm{Fe}$ $0.35 \mathrm{C}-0.15 \mathrm{Nb}$ (wt $\%$, microalloyed steel) were produced by powder metallurgy method. Table 1 shows the average particle sizes and properties of the powders used in experimental studies. SEM images of Fe, Graphite and $\mathrm{Nb}$ powders are given in Figure 2. As can be seen in Figure 2, the iron powder used as a matrix is mostly irregular. Graphite and $\mathrm{Nb}$ powders used as reinforcement elements generally have sharp corners and irregular geometry, similar to each other (Figure $2 b$ and $2 c$ ).

Table 1. Average particle size of powders used in experimental studies and their properties

\begin{tabular}{cccc}
\hline Elemental Powders & Powder Size $(\boldsymbol{\mu m})$ & Purity Value $(\boldsymbol{\%})$ & Supplied Company \\
\hline Iron $(\mathrm{Fe})$ & 43 & 99.9 & Sintek \\
\hline Graphite $(\mathrm{C})$ & $<20$ & 96.5 & Aldrich \\
\hline Niobium $(\mathrm{Nb})$ & $<45$ & 99.8 & Aldrich \\
\hline
\end{tabular}
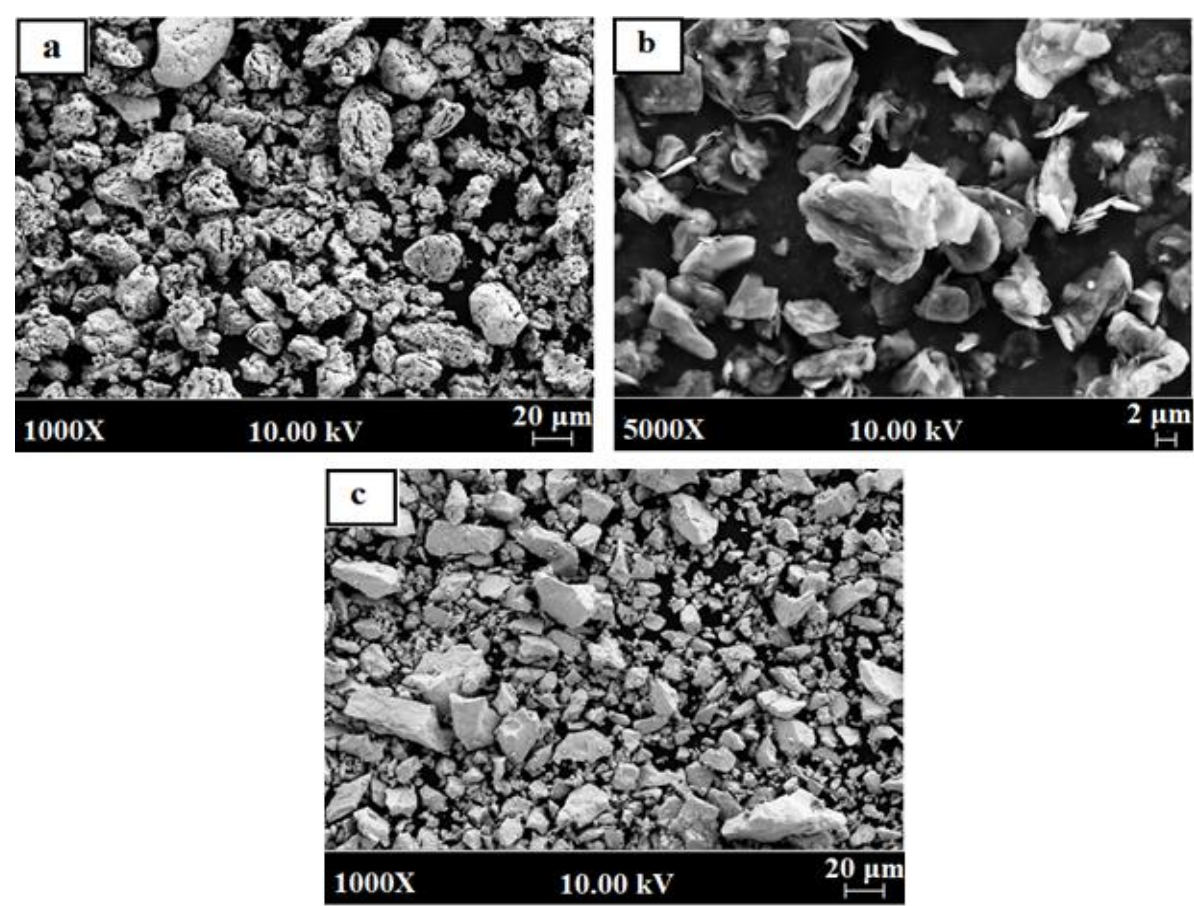

Figure 2. Scanning electron micrographs of Fe, C, and Nb powders (a) Fe $43 \mu \mathrm{m}$; (b) Graphite $<20 \mu \mathrm{m}$ (c) $\mathrm{Nb}<45 \mu \mathrm{m}$

The weighing of the powders at the given chemical composition was carried out on a digital precision balance with a sensitivity of $0.0001 \mathrm{~g}$. Weighed powders were mixed with a three-axis mixer for $1 \mathrm{~h}$ without ball. Mixed powders were pressed at $700 \mathrm{MPa}$. Cylindrical samples with dimensions of $\varnothing 32 \times 29 \mathrm{~mm}$ were produced using a single axis die at room temperature. Pressed samples were sintered at $1150{ }^{\circ} \mathrm{C}$ for $1 \mathrm{~h}$ under argon atmosphere and then cooled down to room temperature in the furnace. One of the samples was homogenized at $1150^{\circ} \mathrm{C}$ for $1 \mathrm{~h}$ and then cooled in air. Other samples were deformed at deformation rates of $40 \%$ and $75 \%$ in an open die under normal atmospheric conditions after homogenization and then allowed to cool in air. The deformation process was carried out at an austenitization temperature between $1150-930{ }^{\circ} \mathrm{C}$. The microstructures of the deformed and non deformed samples were also examined by an optic microscope (Nikon Epiphot 200), Scanning Electron Microscope (Carl Zeiss Ultra Plus Gemini Fesem) and Energy Dispersive Spectrometry (Carl Zeiss Ultra Plus Gemini Fesem). The mean linear 
intercept method was also used to determine average grain size of samples. Vickers hardness measurements were done by using $\mathrm{Hv}_{0.5}(500 \mathrm{~g})$ load (Shimadzu). Figure 3 and 4 show flow chart of experimental procedure and the shape of the produced samples treated under different conditions respectively.

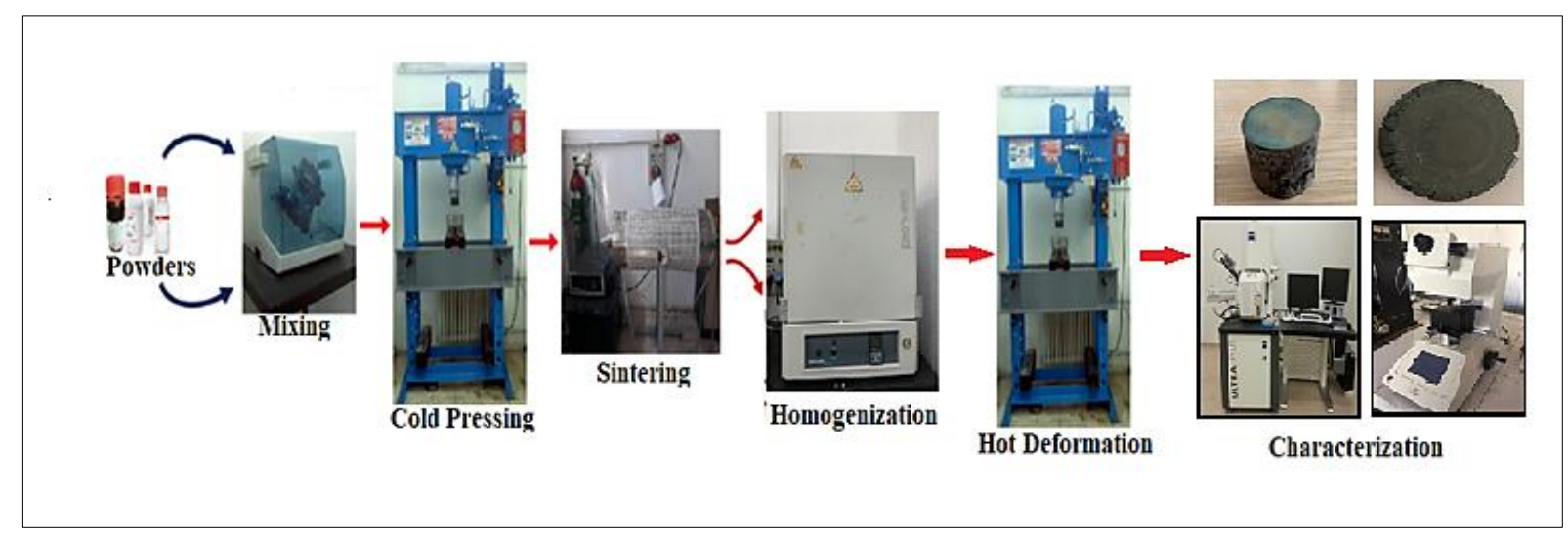

Figure 3. Flow chart of the experimental procedure

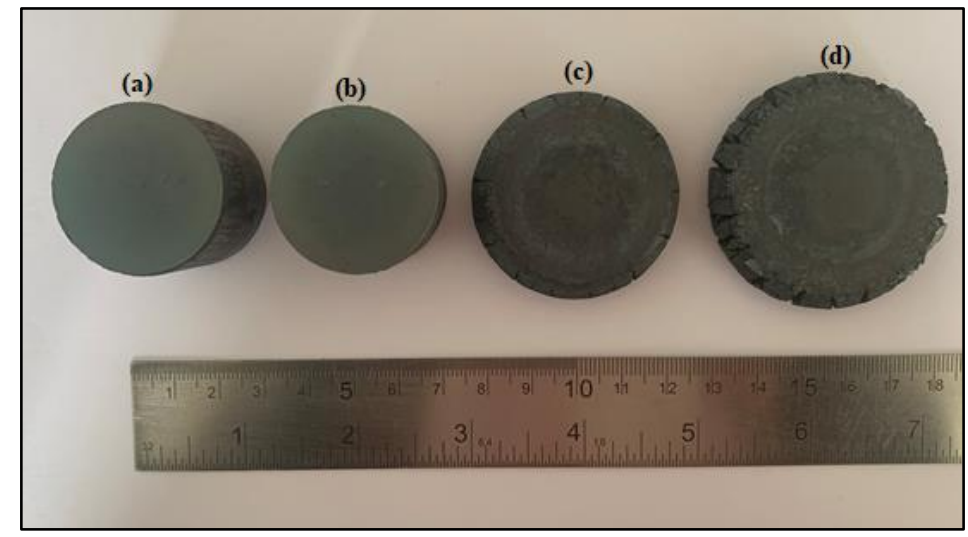

Figure 4. Produced samples a) sintered, b) homogenized, c) $40 \%$ deformed, d) $75 \%$ deformed

\section{RESULTS AND DISCUSSION}

The microstructures of the nonalloyed and $\mathrm{Nb}$ microalloyed steel are seen in Figures 5 and 6 under different conditions; (a) sintered at $1150{ }^{\circ} \mathrm{C}$ for 1 hour, (b) homogenized at $1150{ }^{\circ} \mathrm{C}$ for 1 hour after sintering, (c) $40 \%$ deformed and (d) $75 \%$ deformed. Figures indicated that ferrite and pearlite structures with different equiaxed grain sizes were observed in unalloyed and $\mathrm{Nb}$ microalloyed steels. After the homogenization heat treatment, ferrite and pearlite phases are more homogeneously distributed in the structure. Widmastatten ferrite was also observed in the deformed samples, because deformation effect the nucleation rate of ferrite. It was shown in a study that the nucleation of the ferrite at the grain boundaries of the $30 \%$ deformed samples was 8 times larger than the non deformed samples. This is attributed to the increase in the densities of the strained regions at the austenite grain boundaries which facilitate nucleation rates [2]. In addition deformed samples were cooled in air which is faster than sintered samples cooled in furnace. It is known that Widmanstatten ferrite occured at higher cooling rates than polygonal ferrite formed in the samples cooled in air [20]. Table 2 also shows grain sizes and hardness values of unalloyed and $\mathrm{Nb}$ microalloyed steels for different conditions. As seen in Table 2, the average grain sizes of unalloyed steel were measured as $29.06 \mu \mathrm{m}, 23.32 \mu \mathrm{m}, 14.9 \mu \mathrm{m}$ and $10.71 \mu \mathrm{m}$ for sintered, homogenized, $40 \%$ deformed and $75 \%$ deformed conditions, respectively. The average grain sizes of $\mathrm{Nb}$ microalloyed steel were also measured as $24.17 \mu \mathrm{m}, 18.4 \mu \mathrm{m}, 8.8 \mu \mathrm{m}$ and $5.8 \mu \mathrm{m}$ for sintered, homogenized, $40 \%$ deformed and $75 \%$ deformed conditions, respectively. It was observed that fine-grained microstructure formed in both steels with increasing deformation rate. 

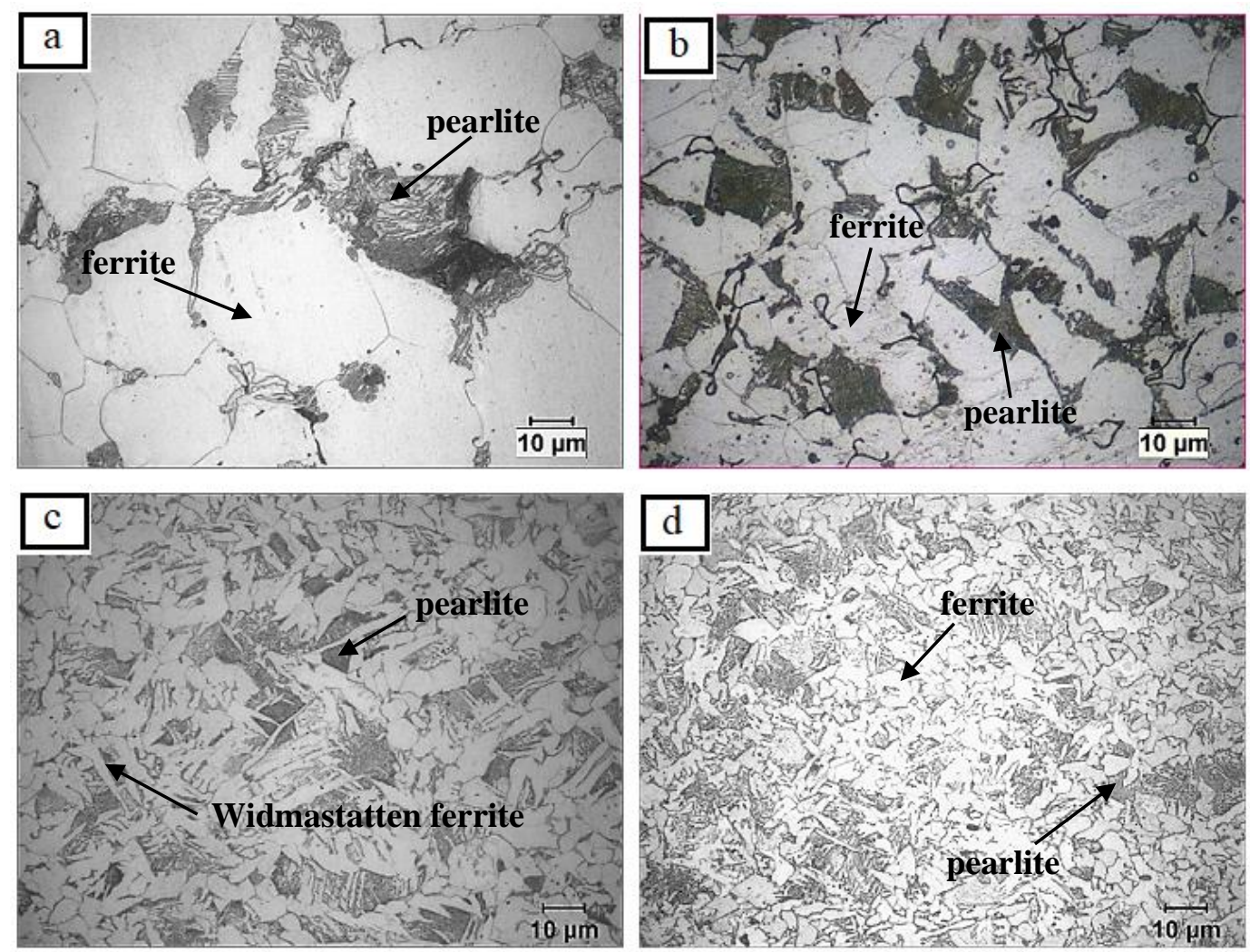

Figure 5. The microstructure of the nonalloyed steel at the centre of the sample, a) sintered for $1 \mathrm{~h}$. at $1150{ }^{\circ} \mathrm{C}, \mathrm{b}$ ) homogenized for $1 \mathrm{~h}$. at $1150{ }^{\circ} \mathrm{C}$ after sintering, c) $40 \%$ deformed, d) $75 \%$ deformed

The microstructure of deformed nonalloyed and $\mathrm{Nb}$ microalloyed samples showed that the grains are not equal and some grains are coarser. The coarser grains are non-recrystallized grains which are surrounded by many small grains. These small grains occurred due to dynamic recrystallization during deformation. This feature strongly proves that the microstructure consisted of noncrystallized and recrystallized grains. However, $\mathrm{Nb}$ microalloyed steel showed smaller grain sizes than the nonalloyed steel for all conditions. A great advantage of microalloying is the limitation of grain growth at the austenite temperatures. The occurrance of small precipitates in austenite during sintering, homogenization or deformation prevents the austenite growth and causes the formation of fine ferrite during cooling [21,22-24]. As is known, the formation of $\mathrm{NbC}$ depends on the amount of deformation rate in the austenite region. Small precipitates prevent recrystallization and create fine ferrite grains [25-27]. SEM images and EDS point analysis of the $\mathrm{Nb}$ microalloyed steel which deformed in austenite region with the deformation rate of $40 \%$ and $75 \%$ are given in Figure 7. The SEM and EDS analysis results confirm that the NbC precipitates occurred in $\mathrm{Nb}$ microalloyed steel after deformation. Precipitates are more effective for the inhibition of the grain growth compared to the dissolved atoms [28].

Microstructure analysis showed that $\mathrm{NbC}$ formed mostly at grain boundaries. These $\mathrm{NbC}$ at the grain boundaries prevented the grain growth leading to a fine grain size in the $\mathrm{Nb}$ microalloyed steel than unalloyed steel. The results of hardness tests were also given in Table 2, showing an increase in hardness values of both steels with increasing the deformation rates. For unalloyed steel, the hardness values obtained from sintered, homogenized, $40 \%$ deformed and $75 \%$ deformed samples were $66 \mathrm{Hv}, 87.64 \mathrm{Hv}, 143 \mathrm{Hv}$, $181 \mathrm{Hv}$, respectively, while the hardness values for $\mathrm{Nb}$ microalloyed steel were $75 \mathrm{Hv}, 144 \mathrm{Hv}, 175 \mathrm{Hv}$, $231 \mathrm{Hv}$, respectively. This increase in hardness can be attributed to the grain refinement occurring in both steels with increasing deformation rate and also to the increase in the amount of $\mathrm{NbC}$ formed in $\mathrm{Nb}$ microalloyed steel. The precipitates formed in $\mathrm{Nb}$ microalloyed steel prevented grain growth and the movement of dislocations, causing the grain size to decrease and the hardness to increase more than unalloyed steel. The effect of microalloy elements on grain boundary movement and recrystallization is a result of carbo-nitride precipitates which may have remained undissolved in austenite or formed during cooling. In addition, the precipitation rate increases with the increase of plastic deformation (strain induced 
precipitation). Inhibition of grain boundary movement by precipitated particles resulted in smaller grain sizes and higher strength [29, 30]. Earlier microhardness studies on ferrite grains [31, 32] showed that the increase in the hardness of microalloyed steels is mainly because of precipitation hardening.
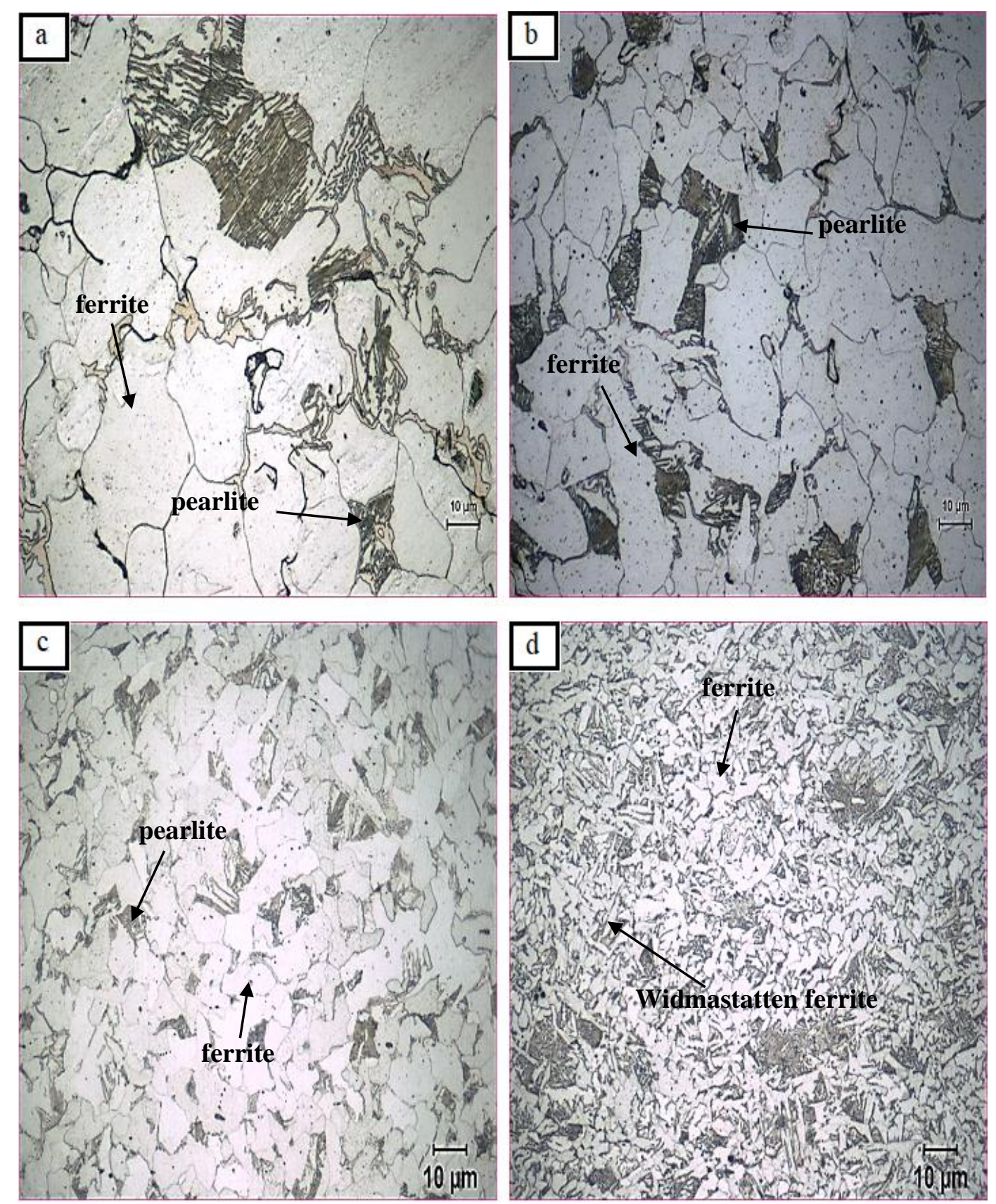

Figure 6. The microstructure of the Nb microalloyed steel at the centre of the sample, a) sintered for $1 \mathrm{~h}$. at $1150{ }^{\circ} \mathrm{C}$, b) homogenized for $1 \mathrm{~h}$. at $1150^{\circ} \mathrm{C}$ after sintering, c) $40 \%$ deformed, d) $75 \%$ deformed 

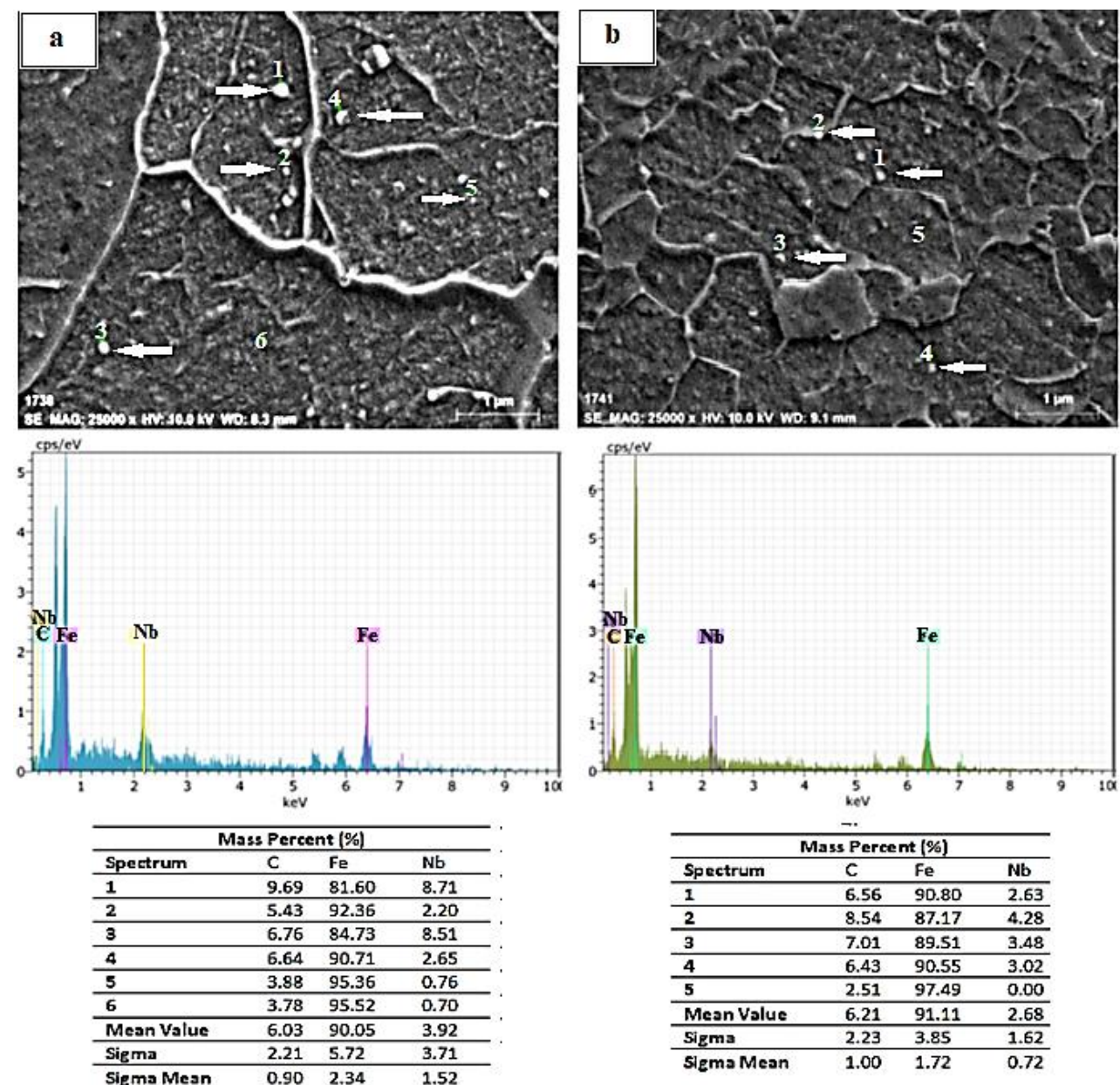

Figure 7. SEM micrograph of Nb microalloyed steel and corresponding EDS of the indicated particles, a) $40 \%$ deformed, $b) 75 \%$ deformed

Table 2. Grain sizes and hardness values of unalloyed steel and Nb microalloyed steel

\begin{tabular}{|l|l|l|l|l|c|}
\hline Nonalloyed Steel & $\begin{array}{l}\text { Grain } \\
\text { Size } \\
(\mu \mathrm{m})\end{array}$ & $\begin{array}{l}\text { Hardness } \\
\left(\mathrm{Hv}_{0.5}\right)\end{array}$ & $\begin{array}{l}\text { Nb } \\
\text { Microalloyed } \\
\text { Steel }\end{array}$ & $\begin{array}{l}\text { Grain } \\
\text { Size } \\
(\mu \mathrm{m})\end{array}$ & $\begin{array}{l}\text { Hardness } \\
\left(\mathrm{Hv}_{0.5}\right)\end{array}$ \\
\hline Sintered & 29.06 & 66 & Sintered & 24.17 & 75 \\
\hline Homogenized & 23.32 & 87.64 & Homogenized & 18.4 & 144 \\
\hline $40 \%$ deformed & 14.9 & 143 & $40 \%$ deformed & 8.8 & 175 \\
\hline $75 \%$ deformed & 10.71 & 181 & $75 \%$ deformed & 5.8 & 231 \\
\hline
\end{tabular}

In addition to grain size refinement and precipitates, changes in density and porosity were also observed. There are some parameters that affect the porosity in powder metallurgy steels. These include alloying, sintering temperature and time, pressing technique such as cold, warm and hot pressing, and deformation rate. Alloying generally increases porosity $[18,33]$, however sintering time and temperature reduce porosity $[33,34]$. Table 3 shows the relative density $(\%)$ of the unalloyed and $\mathrm{Nb}$ microalloyed steels. It is observed that the relative density of both steels increases with the increasing rate of deformation and the percentage porosity decreases, accordingly. The hardness values of specimens produced by powder metallurgy are believed to be also related to amount of the porosity. Since pores may act as a stress raiser and initiate cracks where stress is concentrated, they also contribute to crack propagation if the shape of pore is not aligned [35]. It was observed that the amount of porosity is minimized with increasing deformation rate. As a result of this, hardness of unalloyed and $\mathrm{Nb}$ microalloyed steels resulted in an increase. 
Table 3. Relative density (\%) of unalloyed steel and $\mathrm{Nb}$ microalloyed steel

\begin{tabular}{|c|c|c|c|}
\hline Nonalloyed Steel & $\begin{array}{c}\text { Relative } \\
\text { density (\%) }\end{array}$ & $\begin{array}{c}\text { Nb Microalloyed } \\
\text { Steel }\end{array}$ & $\begin{array}{c}\text { Relative } \\
\text { density (\%) }\end{array}$ \\
\hline Sintered & 90.25 & Sintered & 89.46 \\
\hline Homogenized & 87.81 & Homogenized & 90.07 \\
\hline $40 \%$ deformed & 98.38 & $40 \%$ deformed & 96.75 \\
\hline $75 \%$ deformed & 99.66 & $75 \%$ deformed & 98.51 \\
\hline
\end{tabular}

\section{CONCLUSIONS}

In this study, the thermomechanical processing behaviour of nonalloyed steel and microalloyed steel produced by powder metallurgy method was investigated. The following conclusions obtained from present study are as follows:

1. A fine-grained microstructure developed in both steels with increasing deformation rate. $\mathrm{Nb}$ microalloyed steel has a finer grains than unalloyed steel due to the fact that $\mathrm{NbC}$ prevents grain growth during deformation. While the grain size of unalloyed steel and $\mathrm{Nb}$ microalloyed steel was $29.06 \mu \mathrm{m}$ and $24.17 \mu \mathrm{m}$, respectively, under sintered conditions, the grain size decreased to 10.71 $\mu \mathrm{m}$ and $5.8 \mu \mathrm{m}$, respectively, after $75 \%$ deformation rate.

2. The amount of porosity, which is one of the disadvantages of powder metallurgy, decreased with increasing the deformation rates and the steels became more homogeneous with the increase in density. According to the results, the relative densities of unalloyed steel and $\mathrm{Nb}$ microalloyed steel with a $75 \%$ deformation rate were found to be $99.6 \%$ and $98.5 \%$, respectively.

3. It was observed that $\mathrm{Nb}$ microalloyed steel showed finer microstructure and better mechanical properties then unalloyed steel for all deformation conditions. While the hardness value was 181 $\mathrm{Hv}$ in unalloyed steel, the hardness was obtained as $231 \mathrm{Hv}$ in $\mathrm{Nb}$ microalloy steel under condition of $75 \%$ plastic deformation The reason is that the addition of niobium retarded dynamic recrystallization and the rates of grain growth due to precipitation of $\mathrm{NbC}$ precipitates.

\section{CONFLICTS OF INTEREST}

No conflict of interest was declared by the authors.

\section{ACKNOWLEDGMENTS}

This paper was presented in ICMATSE 20 with ID number 37. This work was supported by Scientific Research Projects Coordination Unit of Karabük University. Project Number: FDK-2020-2318.

\section{REFERENCES}

[1] Shanmugam, S., Misra, R., Mannering, T., Panda, D., and Jansto, S., "Impact toughness and microstructure relationship in niobium and vanadium-microalloyed steels processed with varied cooling rates to similar yield strength”, Materials Science and Engineering: A, 437(2), (2006).

[2] Tamura, I., Ouchi, C., Tanaka, T., and Sekine, H., "Thermomechanical Processing of High-Strength Low-Alloy Steels", Butterworths, Cornwall, (1988).

[3] Gladman, T, "The Physical Metallurgy of Microalloyed Steels. Cambridge: The Institute of Materials", University Press, (1997).

[4] Opiela, M., "Effect of thermomechanical processing on the microstructure and mechanical properties of Nb-Ti-V Microalloyed", Journal of Materials Engineering and Performance, 23: 3379-3388, (2014). 
[5] Eghbali, E., and Abdollah-Zadeh, A., "Influence of Deformation Temperature on the Ferrite Grain Refinement in a Low Carbon Nb-Ti Microalloyed Steel", Journal of Materials Processing Technology, 180: 44-48, (2006).

[6] Grajcar, S. L., "Effect of Nb Microaddition on a Microstructure of Low- Alloyed Steels with Increased Manganese Content", Materials Science Forum., 706-709: 2124-2129, (2012).

[7] Skobir, D.,"High-Strength Low-Alloy (HSLA) Steels", Materials and Technology, 45: 295-301, (2011).

[8] Ghosh, A., Das, S., Chatterjee, S., Mishra, B., Ramachandra Rao, P., "Influence of thermomechanical processing and different post-cooling techniques on structure and properties of an ultra low carbon Cu bearing HSLA forging", Materials Science and Engineering: A, 348 (1-2): 299-308, (2003).

[9] Zhao, M.C., Yang, K., Shan, Y., "The effects of thermo-mechanical control processon microstructures and mechanical properties of a commercial pipeline steel", Materials Science and Engineering: A, 335 (1-2): 14-20, (2002).

[10] Devesh, M., Jansto, S.G., "Niobıum-Based Alloy Design For Structural Applications: ProcessingStructure-Property Paradigm," The Chinese Society for Metals (CSM) and Chinese Academy of Engineering (CAE) TMS, (2016).

[11] Gündüz, S., Erden, M.A., Karabulut, H., Türkmen, M., "Effect of the addition niobium and aluminium on the microstructure and mechanical properties of the micro-alloyed PM steels", Materials and Technology, 50: 641-648, (2016).

[12] Özdemirler D., Gündüz S., Erden M.A., "Influence of NbC Addition on the Sintering Behaviour of Medium Carbon PM Steels", Metals, 7: 121, (2017).

[13] Kannan, R., Shanmugam, S., Narayanasamy, R., "Deformation behaviour of sintered high carbon alloy powder metallurgy steel in powder preform forging", Materials \& Design, 29: 1862-1867, (2008).

[14] Maslyuk, V.A., Orlova, L.N., Kud, V.K., Grabchak, A.K., Mamonova, A.A., Skuratovskii, A.K., "Theory, process technology, articles forming hot-forged wear-resistant powder meterials based on stainless steels of the austenitic class", Powder Metallurgy and Metal Ceramics, 45: 20-27, (2006).

[15] James, W.B., Products, P.F., Corporation, H., Road, R., Lane, T., "New Shaping Methods for Powder Metallurgy Components”, Materials \& Design, 8: 187-197, (1987).

[16] Torralba, J.M.,"Improvement of Mechanical and Physical Properties in Powder Metallurgy", Material Science and Materials Engineering, 3: 281294, (2014).

[17] Türkmen, M., "Effect of carbon content on microstructure and mechanical properties of powder metallurgy steels," Powder Metallurgy and Metal Ceramics, 55: 3-4, (2016).

[18] Erden, M.A., Barlak, S., Adalı, B., Çelikkıran, Ö., "The Effect On Microstructure Mechanical Properties of Vanadium in Nb-V Microalloyed Steel Produced by Powder Metallurgy", Düzce University Journal of Science \& Technology, 6: 629636, (2018).

[19] Tripathy, A., Sarangi, S.K., Chaubey, A.K., "A Review of Solid State Processes in Manufacture of Functionally Graded Materials", International Journal of Engineering \& Technology, 7: 4-39, (2018). 
[20] Zhao, J., Lee, J.H., Kim, Y.W., Jiang, Z., Lee, C.S., "Enhancing mechanical properties of a lowcarbon microalloyed cast steel by controlled heat treatment", Materials Science and Engineering: A, 559: 427-35, (2013).

[21] Gladman, T., "The Physical Metallurgy of Microalloyed Steels. Cambridge: The Institute of Materials", University Press, (1997).

[22] Ollilainen, V., Kasprzak, W., Hollapa, L., "The effect of slicon, vanadium and nitrogen on the microstructure and hardness of air-cooled medium carbon low alloy steel", Journal of Materials Processing Technology, 134: 405-412, (2003).

[23] Xiang-done, H., Xin-ping, M., Sheng-xia, L., "Effect of annealing temperature on recrystallization behavior of cold rolled Ti-microalloyed steel", Journal of Iron and Steel Research International, 20(9): 105-110, (2013).

[24] Shukla, A., K., Singh, P., Vardhan, M., "A two-stage gene selection method for biomarker discovery from microarray data for cancer classification", Chemometrics and Intelligent Laboratory Systems, 183: 47-58, (2018).

[25] Dutta, B., Sellars C. M., "Strengthening of austenite by niobium during hot rolling of microalloyed steel”, Materials Science and Technology, 2: 146-153, (1986).

[26] Sage, A. M., "An overview of the use of micro alloys in hsla steels with particular reference to vanadium and titanium, processing, properties and applications", Proceedings of the Second International Conference on HSLA Steels, 51-61, (1992).

[27] Campos, S.S., Kestenbach, H.J., Morales, E. V., "On strenghening mechanisms in commercial NbTi hot strip steels", Metallurgical and Materials Transactions A, 32A: 245-1248, (2001).

[28] Korczynsky, M., "Microalloying and thermo-mechanical treatment. In Proceedings of the International Symposium on Microstructure and Properties of HSLA Steels', Pittsburgh, PA, USA, 3-5: 169-201, (1987).

[29] Kostryzhev, A.G, Al Shahrani, A., Zhu, C., Cairney, J.M., Ringer, S.P., Killmore, C.R., "Effect of niobium clustering and precipitation on strength of an NbTi-microalloyed ferritic steel", Materials Science and Engineering: A, 607: 226-235, (2014).

[30] Erden, M.A., Gündüz, S., Türkmen, M., Karabulut, H., "Microstructural characterization and mechanical properties of microalloyed powder metallurgy steels", Materials Science and Engineering: A, 616: 201-206, (2014).

[31] Guang, X., Xiaolong, G., Guojun, M., Feng, L., Hang, Z., "The development of Ti alloyed high strength microalloy steel”, Materials \& Design, 31: 2891-2896, (2010).

[32] Chokkalingam, B., MohamedNazirudeen, S.S., Ramakrishnan, S.S., "Investigation into the mechanical properties of Micro-alloyed as-cast steel", Materials and Technology, 45: 159-162, (2011).

[33] Erden, M.A., "The Effect of the Sintering Temperature and Addition of Niobium and Vanadium on the Microstructure and Mechanical Properties of Microalloyed PM Steels", Metals, 7: 329, (2017).

[34] Erden, M.A., "The Effect of Sintering Time on Tensile Strength of NB-V Microalloyed Powder Metallurgy Steels", E-Journal of New World Sciences Academy, 15, 15-22, (2020). 
[35] Sarıtaş, S., Türker, M., Durlu, N., "Powder metallurgy and particulate material processes”, Turkish Powder Metallurgy Publications, Ankara, (2007). 